\title{
Influence of Crop Growth Stages and Management Practices on Soil Water Content at Different Soil Depths under Dryland Conditions
}

\author{
E. T. Sebetha ${ }^{1} \&$ A. T. Modi $^{2}$ \\ ${ }^{1}$ Crop Science Department, School of Agriculture, Science and Technology, North-West University, Mafikeng \\ Campus, Mmabatho, South Africa \\ ${ }^{2}$ Crop Science, School of Agriculture, Earth and Environmental Sciences, University of KwaZulu-Natal, \\ Scottsville, South Africa \\ Correspondence: E. T. Sebetha, Crop Science, School of Agriculture, Earth and Environmental Sciences, \\ University of KwaZulu-Natal, Private Bag x 01, Scottsville 3209, South Africa. E-mail: erick.sebetha@nwu.ac.za
}

Received: July 11, 2017

doi:10.5539/jas.v9n11p88

\author{
Accepted: August 30, $2017 \quad$ Online Published: October 15, 2017 \\ URL: https://doi.org/10.5539/jas.v9n11p88
}

\begin{abstract}
Soil water loss through evaporation plays a role on low crop productivity and this is due to poor cropping systems and soil surface coverage. The study was carried out at three locations of North-West province of South Africa, which were Potchefstroom, Taung and Rustenburg during 2011/12 and 2012/13 planting seasons. The experimental design was a factorial experiment laid out in a randomised complete block design (RCBD) with three replicates. The experiment consisted of five cropping systems, which were monocropping cowpea, monocropping maize, cowpea followed by maize in rotation, maize followed by cowpea in rotation and intercropping maize-cowpea. The three crop growth stages compared in this study were before tasselling/flowering, during tasselling/pod formation and during physiological maturity of maize and cowpea. Soil was sampled for the 0-0.15, 0.15-0.3, 0.3-0.6 and 0.6-0.9 $\mathrm{m}$ depth increments and soil water content determined using the Gravimetric method. The crop growth stage before tasselling/flowering in maize/cowpea had significantly $(\mathrm{P}<0.05)$ higher water content of $10.2,10.8,12.5$ and $13.3 \%$ at the depth of $0-0.15,0.15-0.3$, 0.3-0.6 and 0.6-0.9 m respectively. Soil collected at Rustenburg and Potchefstroom had significantly $(\mathrm{P}<0.05)$ higher water content of 13.5 and $10.2 ; 15.9$ and $10.9 ; 18.3$ and $12.8 ; 18.4$ and $14.5 \%$ at the depths of $0-0.15$, 0.15-0.3, 0.3-0.6 and 0.6-0.9 m respectively. Monocropping cowpea plots had significantly $(\mathrm{P}<0.05)$ higher water content of $12.4 \%$ than other cropping systems at the soil depth of 0.3-0.6 m. Monocropping plots of cowpea had the ability to hold soil water and this depends on the type of cowpea cultivar and canopy cover. The stage before tasselling/flowering of maize-cowpea $(\mathrm{V} 10 / \mathrm{Vn})$ was found to have high soil water content. Soil water content differs across locations due to different soil physical properties.
\end{abstract}

Keywords: cropping system, gravimetric water content, monocropping cowpea

\section{Introduction}

Soil and water conservation is one of the cardinal principles of land management in rainfed areas with considerable potential for increased productivity. Soil water availability is controlled by matric potential at which the water is held (Panday \& Nkongolo, 2015). Matric potential depends on soil water content, the size of soil pores, the surface proportion of soil particles and surface tension of soil water (Whalley et al., 2013). Soil texture has profound effect on water retention and is considerably most important among physical properties (Schoonover \& Crim, 2015). Sandy soil has low water retention, low organic matter and high infiltration (Abdel-Nasser et al., 2007). It was further indicated that soil with high percentage of organic matter and natural deposits rich in clay content caused an increase in water holding capacity and reduction in evaporation (Parikh \& James, 2012). The soil's ability to retain water is strongly related to particle size (Leeper \& Uren, 1993). Water retention is positively correlated with the clay content because of the occurrence of micropores and menisci that generate capillary forces (Reichert et al., 2009). Clay increases specific area of soil matrix and water adsorption (Hillel, 1998).

Crops such as maize (Zea mays) have different responses to water deficit according to their developmental stages (Cakir, 2004). During stem elongation of maize (after floral initiation), leaves and stems grow rapidly, requiring adequate supplies of water to sustain rapid organ development (Muchow, 1989). Soil water shortage was 
damaging to grain yield if it occurred early in the growing season, at flowering and during grain filling (Heisey \& Edmeades, 1999). Cowpea can tolerate drought stress at the vegetative stage, and recover when water is available at the reproductive stage to produce seed yield equivalent to that of unstressed plants. Drought stress at the flowering or pod filling stage of cowpea reduced yield (Akyeampong, 1985). Excess water may limit yields through nutrient losses from soil (Nandwa \& Chege, 1996).

Crop canopy coverage conserves soil water, since shaded soil surface receives very little radiation and its temperature becomes lower than exposed soil (Hsiao \& Xu, 2005). An intercrop of two crop species such as legumes and cereals may use water more efficiently than a monoculture of their species through exploring a larger total soil volume for water, especially if the component crops have different rooting patterns (Ofori et al., 2014). It was further indicated that, the intercrop recorded the highest water use efficiency followed by the maize sole crop and lastly the cowpea sole crops (Ofori et al., 2014). The soil water depletion can be minimized by the use of cover crops (Unger \& Vigil, 1998). The effective of cover crops in maintaining or improving soil water storage depends on factors such as method of planting and stage of growth. The methods of planting such as rotation have been reported to improve soil water content (Roder et al., 1989). The influence of cropping systems in terms of maize/legume rotation, intercropping and monocropping on soil water content is not known to most farmers. The stages of crop growth which play a role on soil water conservation is also not identified by most farmers. Therefore, the objective of this study was to determine the effect of cropping system, crop growth stages and location on soil water content.

\section{Materials and Methods}

\subsection{Site Description}

The study was conducted at three dryland localities in South Africa; Department of Agriculture Experimental Station in Taung situated $\left(27^{\circ} 32^{\prime} 0^{\prime \prime} \mathrm{S} 24^{\circ} 47^{\prime} 8^{\prime \prime} \mathrm{E}\right)$, Agriculture Research Council-Grain Crops Institute (ARC-GCI) experimental station in Potchefstroom $\left(26^{\circ} 42^{\prime} 54^{\prime \prime} \mathrm{S} 27^{\circ} 06^{\prime} 12^{\prime \prime} \mathrm{E}\right)$ and Agriculture Research Council-Institute for Industrial Crops (ARC-IIC) experimental station in Rustenburg (25040'51.4" $\left.27^{\circ} 13^{\prime} 58.4^{\prime \prime} \mathrm{E}\right)$ Taung experimental station is situated in grassland savannah with annual mean rainfall of $1061 \mathrm{~mm}$ that begins in October. The average clay content of this location is $8 \%$. The soil at Taung is described as Hutton, deep, fine sandy dominated red freely drained, eutrophic with parent material that originated from Aeolian deposits (Soil Classification Working Group, 1991). The ARC-GCI experimental station soil has a clay content of about $30 \%$ and the location receives annual mean rainfall of $622.2 \mathrm{~mm}$ (Macvicar et al., 1977). Potchefstroom (ARC-GCI) has plinthic catena soil, eutrophic, red soil widespread (Pule-Meulenberg et al., 2010). The ARC-IIC experimental station soil has a clay content of approximately $49.5 \%$ and receives an annual rainfall of $661 \mathrm{~mm}$. The soil at Rustenburg (ARC-IIC) has dark, olive grey and clay soil, bristle consistency, medium granular structure (Botha et al., 1968). Baseline soil analysis performed before planting indicated amounts of 5,8 and $6.5 \mathrm{~kg}$ of $\mathrm{N} \mathrm{ha}^{-1}$ available at Potchefstroom, Rustenburg and Taung, respectively. The soil physical properties analysed from three locations before planting are indicated in Table 1. The monthly mean temperature and rainfall data for Potchefstroom, Taung and Rustenburg for the duration of experimental period is indicated in Table 2 as described by Sebetha et al. (2015).

Table 1. Soil texture properties of the three experimental locations

\begin{tabular}{llll}
\hline \multirow{2}{*}{ Location } & \multirow{2}{*}{ Physical properties } & \multicolumn{2}{c}{ Soil depth } \\
\cline { 3 - 4 } & & $0-15 \mathrm{~cm}$ & $15-30 \mathrm{~cm}$ \\
\hline Potchefstroom & \% Sand & 58 & 58 \\
& \% Silt & 12 & 13 \\
& \% Clay & 30 & 29 \\
\hline Taung & \% Sand & 91 & 91 \\
& \% Silt & 1 & 1 \\
\hdashline \% Clay & 8 & 8 \\
\hline \% Sand & 44 & 42 \\
& \% Silt & 7 & 8 \\
& \% Clay & 49 & 50 \\
\hline
\end{tabular}


Table 2. The monthly mean temperature and rainfall data for Potchefstroom, Taung and Rustenburg for the duration of experimental period

\begin{tabular}{|c|c|c|c|c|c|c|c|c|c|c|}
\hline Site & Season & Climate data & Oct & Nov & Dec & Jan & Feb & Mar & Apr & May \\
\hline \multirow[t]{6}{*}{ Potch } & \multirow[t]{3}{*}{$2011 / 12$} & Rainfall (mm) & 35.58 & 66.29 & 75.95 & 19.05 & 33.78 & 66.29 & 4.32 & 0 \\
\hline & & $\operatorname{Max} T\left({ }^{\circ} \mathrm{C}\right)$ & 28.64 & 29.45 & 28.57 & 30.42 & 29.11 & 28.72 & 25.00 & 25.00 \\
\hline & & $\operatorname{Min} T\left({ }^{\circ} \mathrm{C}\right)$ & 11.19 & 13.78 & 15.81 & 16.22 & 16.30 & 13.59 & 8.05 & 5.17 \\
\hline & \multirow[t]{3}{*}{$2012 / 13$} & Rainfall (mm) & 21.84 & 13.46 & 42.42 & 45.72 & 28.7 & 43.94 & $47.5^{-}$ & 8.14 \\
\hline & & $\operatorname{Max} T\left({ }^{\circ} \mathrm{C}\right)$ & 29.01 & 30.21 & 27.99 & 30.11 & 31.03 & 28.43 & 24.32 & 22.61 \\
\hline & & $\operatorname{Min} \mathrm{T}\left({ }^{\circ} \mathrm{C}\right)$ & 12.43 & 14.62 & 15.41 & 16.81 & 15.5 & 14.58 & 9.12 & 3.86 \\
\hline \multirow[t]{6}{*}{ Taung } & \multirow[t]{3}{*}{ 2011/12 } & Rainfall (mm) & 3.05 & 36.07 & 71.37 & 7.87 & 40.89 & 12.45 & 5.08 & 0.51 \\
\hline & & $\operatorname{Max} T\left({ }^{\circ} \mathrm{C}\right)$ & 31.05 & 33.28 & 32.8 & 36.12 & 32.87 & 32.96 & 28.02 & 27.65 \\
\hline & & $\operatorname{Min} \mathrm{T}\left({ }^{\circ} \mathrm{C}\right)$ & 9.25 & 10.6 & 14.79 & 16.19 & 17.01 & 13.75 & 8.24 & 4.48 \\
\hline & \multirow[t]{3}{*}{$2012 / 13$} & Rainfall $(\mathrm{mm})$ & 0.25 & 8.89 & 14.99 & 40.89 & 32.00 & 14.2 & 9.2 & 8.4 \\
\hline & & $\operatorname{Max} T\left({ }^{\circ} \mathrm{C}\right)$ & 32.5 & 34.98 & 32.86 & 36.29 & 31.5 & 31.8 & 27.3 & 26.8 \\
\hline & & $\operatorname{Min} T\left({ }^{\circ} \mathrm{C}\right)$ & 10.74 & 14.27 & 15.71 & 17.83 & 17.7 & 15 & 9.4 & 6.2 \\
\hline \multirow[t]{6}{*}{ Rust } & \multirow[t]{3}{*}{$2011 / 12$} & Rainfall (mm) & 23.37 & 49.79 & 47.24 & 19.3 & 6.35 & 27.94 & 6.6 & 0.25 \\
\hline & & $\operatorname{Max} T\left({ }^{\circ} \mathrm{C}\right)$ & 28.68 & 30.18 & 28.28 & 30.20 & 30.95 & 29.00 & 25.04 & 25.13 \\
\hline & & $\operatorname{Min} \mathrm{T}\left({ }^{\circ} \mathrm{C}\right)$ & 11.71 & 14.91 & 17.00 & 15.34 & 17.21 & 14.37 & 9.34 & 6.58 \\
\hline & \multirow[t]{3}{*}{$2012 / 13$} & Rainfall (mm) & 21.08 & 25.91 & 48.01 & 37.34 & 20.58 & 10.92 & 46.48 & 0 \\
\hline & & $\operatorname{Max} T\left({ }^{\circ} \mathrm{C}\right)$ & 28.28 & 29.95 & 28.13 & 29.9 & 31.05 & 29.05 & 25.48 & 23.23 \\
\hline & & $\operatorname{Min} T\left({ }^{\circ} \mathrm{C}\right)$ & 12.82 & 14.76 & 16.14 & 17.38 & 16.28 & 14.67 & 10.17 & 4.68 \\
\hline
\end{tabular}

Note. Potch $=$ Potchefstroom, Rust $=$ Rustenburg, $\operatorname{Max} \mathrm{T}\left({ }^{\circ} \mathrm{C}\right)=$ Maximum temperature in decrees Celsius, Min T $\left({ }^{\circ} \mathrm{C}\right)=$ Minimum temperature in decrees Celsius, $\mathrm{mm}=$ millimetres.

\subsection{Experimental Design and Treatments}

The experimental design was a factorial experiment laid out in randomised complete block design (RCBD) with three replicates per location. The study was carried out at three locations of North-West province of South Africa, which were Potchefstroom, Taung and Rustenburg during 2011/12 and 2012/13 planting seasons. The experiment consisted of five cropping systems, which were cowpea monocrop, maize monocrop, cowpea followed by maize in rotation, maize followed by cowpea in rotation and intercropping maize-cowpea. These cropping systems are more popular and practised by small scale and commercial maize/legume farmers in Southern Africa. The three growth stages compared in this study were V10/Vn, VT/R4 and R6/R8 stages of maize/cowpea respectively as described in Table 3 . These stages are the most critical period of crop development and the water demand by crops is high during those stages. The lack of soil water during those stages results in reduction of yield in both crops.

Table 3. Description of plant growth stages in maize and cowpea

\begin{tabular}{lll}
\hline Crop & Growth stage & Description \\
\hline Cowpea & Vn & Before flowering \\
& R4 & During pod formation \\
& R8 & During physiological maturity \\
Maize & V10 & Before tasselling \\
& VT & During ear formation \\
& R6 & During physiological maturity \\
\hline
\end{tabular}

\subsection{Agronomic/Field Practices}

Based on previous studies performed on the selected locations, the optimum $\mathrm{N}$ rate to be applied on maize was $100 \mathrm{~kg} \mathrm{ha}^{-1}$ at Potchefstroom and Rustenburg and $120 \mathrm{~kg} \mathrm{ha}^{-1}$ at Taung. For cowpea, the optimum $\mathrm{N}$ rate to be applied was $25 \mathrm{~kg} \mathrm{ha}^{-1}$ at Potchefstroom and Rustenburg, and $30 \mathrm{~kg} \mathrm{ha}^{-1}$ at Taung. Based on the above information, two levels of $\mathrm{N}$ fertilization to the amount of 0 and 95; 0 and 92; 0 and $113.5 \mathrm{~kg}$ of N ha ${ }^{-1}$ were applied during planting on maize plots at Potchefstroom, Rustenburg and Taung, respectively. The amount of 0 and 20; 0 and 17; 0 and $23.5 \mathrm{~kg}$ of $\mathrm{N} \mathrm{ha}^{-1}$ were applied during planting on cowpea plots at Potchefstroom, 
Rustenburg and Taung respectively. Maize (Zea mays L. cultivar PAN 6479) and cowpea (Vigna unguiculata L. cultivar Bechuana White) were used as test crops.

\subsection{Soil Sampling and Analysis}

The experiment commenced in November/December of 2010/11 planting season, and the data were collected during the 2011/12 and 2012/13 planting seasons. In this study, the soil water content up to $0.9 \mathrm{~m}$ deep was evaluated in five cropping systems at three different growth stages at different locations. The evaluation was performed at different growth stages of maize and cowpea. Soil samples were collected at the depth of 0-0.15, 0.15-0.3, 0.3-0.6 and 0.6-0.90 m during V10/Vn, VT/R4 and R6/R8 stages of maize/cowpea respectively. The samples were collected from each plot using soil auger. Soil samples were put inside plastic bags during collection at the field, sealed and kept at cold room to avoid water loss. The gravimetric water content (GWC) method was used to determine the soil water content (Black, 1965). Each porcelain tin was weighed and tarred before weighing of 10 grams of soil. Samples were oven dried at $105{ }^{\circ} \mathrm{C}$ for 24 hours. The samples were returned to the oven to dry for several hours, until there was no difference between any two consecutive measurements of the weight of dry soil + tare. GWC is calculated using the formula as:

$$
\text { GWC }=\frac{(\text { Weight of wet soil }+ \text { Tare })-(\text { Weight of dry soil }+ \text { Tare })}{(\text { Weight of dry soil }+ \text { Tare })-\text { Tare }}
$$

\subsection{Statistical Analysis}

Analysis of variance was performed using GenStat $15^{\text {th }}$ edition (2012). Least significant difference (LSD) was used to separate means. A probability level of less than 0.05 was considered to be statistically significant (K. A. Gomez \& A. A. Gomez, 1984).

\section{Results}

\subsection{The Influence of Crop Growth Stages and Management Practices on Soil Water Content at the Depth of} $0-0.15 \mathrm{~m}$

Crop growth stages had significant effect $(\mathrm{P}<0.001)$ on soil water content at the soil depth of $0-0.15 \mathrm{~m}$ as indicated in Table 4. The crop growth stages $\mathrm{V} 10 / \mathrm{Vn}$ and R6/R8 of maize/cowpea had significantly $(\mathrm{P}<0.05)$ higher water content of 10.2 and $9.1 \%$ respectively than soil collected during VT/R4 stage. Location also had significant effect $(\mathrm{P}<0.001)$ on soil water content. Soil collected at Rustenburg and Potchefstroom had significantly $(\mathrm{P}<0.05)$ higher water content of 13.5 and $10.2 \%$ respectively than soil collected at Taung. Season also showed significant effect $(\mathrm{P}<0.001)$ on soil water content. The soil collected during 2012/13 planting season had significantly $(P<0.05)$ higher soil water content of $9.9 \%$ than soil collected during 2011/12 planting season. The interaction of crop growth stages $\times$ location $\mathrm{x}$ season $(\mathrm{P}<0.001)$ had significant effect on soil water content.

Table 4. The influence of crop growth stages and management practices on soil water content in percentages at $0-0.15 \mathrm{~m}$ depth

\begin{tabular}{llllll}
\hline Cropping system & Inter M/C & Monocowpea & Monomaize & Maize-cowpea Rot & Cowpea-maize Rot \\
\hline Means & & & & & 9.1 \\
LSD $_{(0.05)}$ & 9.3 & 9.5 & 9.3 & 9.3 & \\
\hline Crop growth stages & 0.36 & & & & \\
\hline Means & $10 / \mathrm{Vn}$ & $\mathrm{R} 6 / \mathrm{R} 8$ & VT/R4 & & \\
LSD $_{(0.05)}$ & 0.3 & 9.1 & 8.6 & & \\
\hline Location & Potch & Rust & Taung & & \\
\hline Means & 10.2 & 13.5 & 4.1 & & \\
LSD & & & & \\
\hline Season & 0.3 & & & & \\
\hline Means $_{\text {LSD }_{(0.05)}}$ & $2011 / 12$ & $2012 / 13$ & & & \\
\hline
\end{tabular}

Note. Inter $\mathrm{M} / \mathrm{C}=$ Intercropping of maize and cowpea; Monocowpea $=$ Monocropping cowpea; Monomaize $=$ Monocropping maize; Maize-cowpea Rot $=$ Maize followed by cowpea in rotation; Cowpea-maize Rot $=$ Cowpea followed by maize in rotation; Potch $=$ Potchefstroom; Rust $=$ Rustenburg. 


\subsection{The Influence of Crop Growth Stages and Management Practices on Soil Water Content at the Depth of} $0.15-0.3 \mathrm{~m}$

Crop growth stages had significant effect $(\mathrm{P}<0.001)$ on soil water content at the depth of $0.15-0.3 \mathrm{~m}$ as indicated in Table 5. The crop growth stages V10/Vn and R6/R8 of maize/cowpea had significantly $(\mathrm{P}<0.05)$ higher soil water content of 10.8 and $10.7 \%$ than soil collected during VT/R4 stage. Location also had significant effect $(\mathrm{P}<0.001)$ on soil water content. Soil collected at Rustenburg and Potchefstroom had significantly higher water content of 15.9 and $10.9 \%$ than soil collected at Taung. The interaction of crop growth stages $\times$ location $\times$ season $(\mathrm{P}<0.01)$ had significant effect on soil water content.

Table 5. The influence of crop growth stages and management practices on soil water content in percentages at $0.15-0.3 \mathrm{~m}$ soil depth

\begin{tabular}{|c|c|c|c|c|c|}
\hline Cropping system & Inter $\mathrm{M} / \mathrm{C}$ & Monocowpea & Monomaize & Maize-cowpea Rot & Cowpea-maize Rot \\
\hline Means & 10.4 & 10.9 & 10.4 & 10.3 & 10.4 \\
\hline $\operatorname{LSD}_{(0.05)}$ & 0.4 & & & & \\
\hline Crop growth stages & $\mathrm{V} 10 / \mathrm{Vn}$ & R6/R8 & VT/R4 & & \\
\hline Means & 10.8 & 10.7 & 9.9 & & \\
\hline $\operatorname{LSD}_{(0.05)}$ & 0.3 & & & & \\
\hline Location & Potch & Rust & Taung & & \\
\hline Means & 10.9 & 15.9 & 4.7 & & \\
\hline $\operatorname{LSD}_{(0.05)}$ & 0.3 & & & & \\
\hline Season & $2011 / 12$ & $2012 / 13$ & & & \\
\hline Means & 10.5 & 10.5 & & & \\
\hline $\operatorname{LSD}_{(0.05)}$ & 0.3 & & & & \\
\hline
\end{tabular}

Note. Inter $\mathrm{M} / \mathrm{C}=$ Intercropping of maize and cowpea; Monocowpea $=$ Monocropping cowpea; Monomaize $=$ Monocropping maize; Maize-cowpea Rot $=$ Maize followed by cowpea in rotation; Cowpea-maize Rot $=$ Cowpea followed by maize in rotation; Potch $=$ Potchefstroom; Rust $=$ Rustenburg.

\subsection{The Influence of Crop Growth Stages and Management Practices on Soil Water Content at the Depth of $0.3-0.6 \mathrm{~m}$}

Cropping system had significant effect $(\mathrm{P}=0.029)$ on soil water content at soil depth of 0.3-0.6 $\mathrm{m}$ as indicated in Table 6. Monocropping cowpea plots had significantly $(\mathrm{P}<0.05)$ higher soil water content of $12.4 \%$ than other cropping systems. Crop growth stages had significant effect $(\mathrm{P}<0.001)$ on soil water content. The crop growth stage V10/Vn of maize/cowpea had significantly $(\mathrm{P}<0.05)$ higher soil water content of $12.5 \%$ than VT/R4 and R6/R8 stages. Location also had significant effect $(\mathrm{P}<0.001)$ on soil water content. Soil collected at Rustenburg and Potchefstroom had significantly $(\mathrm{P}<0.001)$ higher water content of 18.3 and $12.8 \%$ respectively than soil collected at Taung. Season also showed significant effect $(\mathrm{P}<0.001)$ on soil water content. The soil collected during 2011/12 planting season had significantly $(\mathrm{P}<0.05)$ higher water content of $12.3 \%$ than soil collected at $2012 / 13$ planting season. The interaction of cropping system $\times$ location $\times$ season $(\mathrm{P}=0.014)$ had significant effect on soil water content. 
Table 6. The influence of crop growth stages and management practices on soil water content in percentages at 0.3-0.6 m soil depth

\begin{tabular}{llllll}
\hline Cropping system & Inter M/C & Monocowpea & Monomaize & Maize-cowpea Rot & Cowpea-maize Rot \\
\hline Means & 11.8 & 12.4 & 11.9 & 11.9 & 11.8 \\
LSD $_{(0.05)}$ & 0.4 & & & & \\
\hline Crop growth stages & V10/Vn & R6/R8 & VT/R4 & \\
\hline Means & 12.5 & 11.8 & 11.6 & \\
LSD $_{(0.05)}$ & 0.3 & & & \\
\hline Location & Potch & Rust & Taung & \\
\hline Means & 12.8 & 18.3 & 4.8 & \\
LSD & & & \\
\hline Season & 0.3 & & & \\
\hline Means $_{\text {LSD }}(0.05)$ & $2011 / 12$ & $2012 / 13$ & & \\
\hline
\end{tabular}

Note. Inter $\mathrm{M} / \mathrm{C}=$ Intercropping of maize and cowpea; Monocowpea = Monocropping cowpea; Monomaize $=$ Monocropping maize; Maize-cowpea Rot = Maize followed by cowpea in rotation; Cowpea-maize Rot = Cowpea followed by maize in rotation; Potch $=$ Potchefstroom; Rust $=$ Rustenburg.

\subsection{The Influence of Crop Growth Stages and Management Practices on Soil Water Content at the Depth of $0.6-0.9 \mathrm{~m}$}

Crop growth stages had significant effect $(\mathrm{P}<0.001)$ on soil water content at the depth of $0.6-0.9 \mathrm{~m}$ as indicated in Table 7. The crop growth stage V10/Vn had significantly $(\mathrm{P}<0.05)$ higher soil water content of $13.3 \%$ than VT/R4 and R6/R8 stages. Location also had significant effect $(\mathrm{P}<0.001)$ on soil water content. Soil collected at Rustenburg and Potchefstroom had significantly $(\mathrm{P}<0.05)$ higher water content of 18.4 and $14.5 \%$ respectively than soil collected at Taung. Season also showed significant effect $(\mathrm{P}<0.001)$ on soil water content. The soil collected during 2011/12 planting season had significantly $(\mathrm{P}<0.05)$ higher water content of $13.1 \%$ than soil collected during 2012/13 planting season. The interaction of crop growth stage $\times$ location $\times$ season $(\mathrm{P}=0.034)$ had significant effect on soil water content.

Table 7. The influence of crop growth stages and management practices on soil water content in percentages at 0.6-0.9 m soil depth

\begin{tabular}{llllll}
\hline Cropping system & Inter M/C & Monocowpea & Monomaize & Maize-cowpea Rot & Cowpea-maize Rot \\
\hline Means & 12.4 & 12.7 & 12.7 & 12.4 & 12.6 \\
LSD $_{(0.05)}$ & 0.4 & & & \\
\hline Crop growth stages & V10/Vn & R6/R8 & VT/R4 & & \\
\hline Means & 13.3 & 12.1 & 12.3 & \\
LSD $_{(0.05)}$ & 0.3 & & & \\
\hline Location & Potch & Rust & Taung & \\
\hline Means & 14.6 & 18.4 & 4.7 & \\
LSD $_{(0.05)}$ & 0.3 & & & \\
\hline Season & $2011 / 12$ & $2012 / 13$ & & \\
\hline Means & 13.1 & 12.1 & & \\
LSD $_{(0.05)}$ & 0.2 & & & \\
\hline
\end{tabular}

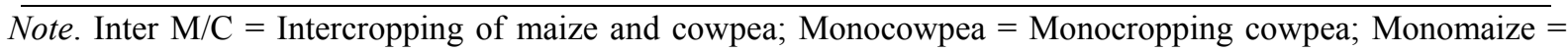
Monocropping maize; Maize-cowpea Rot = Maize followed by cowpea in rotation; Cowpea-maize Rot = Cowpea followed by maize in rotation; Potch $=$ Potchefstroom; Rust $=$ Rustenburg.

\subsection{Correlation between Soil Water Content and Maize/Cowpea Grain Yield}

There was no correlation between soil water content and maize grain yield during both planting seasons at physiological maturity as indicated in Figure 1a up to Figure 4b. There was also no correlation between soil 
water content and cowpea grain yield during 2011/12 planting season at physiological maturity as indicated in Figures 5a, 6a, 7a and 8a. There was positive correlation between soil water content and cowpea grain yield during 2012/13 planting season at physiological maturity as indicated in Figures 5b, 6b, 7b and 8b.

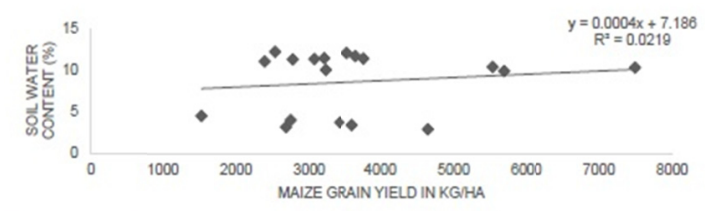

Figure 1a. Sol water content at the depth of 0-0.15 m and maize yield correlation during 2011/12 planting season.

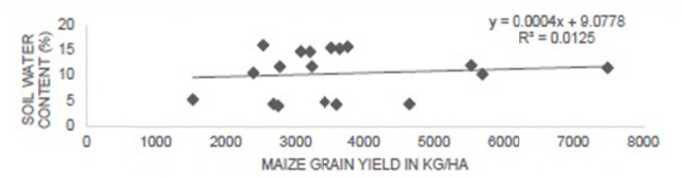

Figure 2a. Soll water content at the depth of $0.15-0.30 \mathrm{~m}$ and maize yeld correlation during 2011/12 planting season.

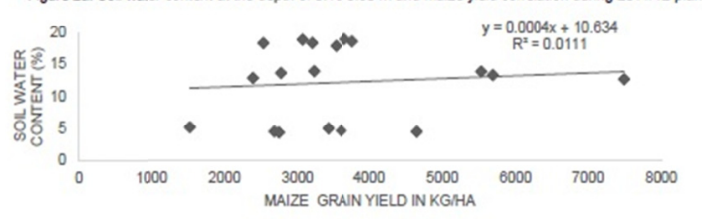

Figure 3a. Sol wzer content at the depch of $0.30-0.80 \mathrm{~m}$ and maize yeld corelation during 2011/12 planting seasons.

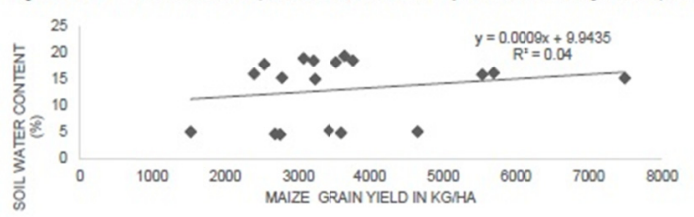

Figure 4a. Soll water content at the depth of $0.00-0.90 \mathrm{~m}$ and maize yield correlation during 2011/12 planting season.

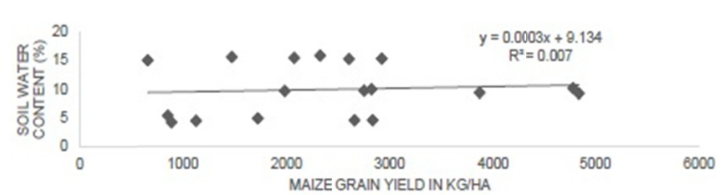

Figure 16 . Sol water content 3 the depth of 0-0.15 m and maize yield correation during 2012/13 planting season.

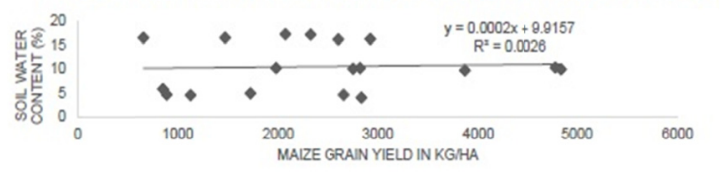

Figure 2b. Soll water content at the depth of $0.15-0.30 \mathrm{~m}$ and maze yeld correlation durng 2012/13 planting season. 爯

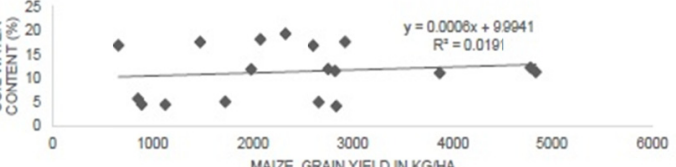

Figure 3b. Sol water content 3 the depth of $0.30-0.60 \mathrm{~m}$ and maize yield correlation during 2012/13 planting season.

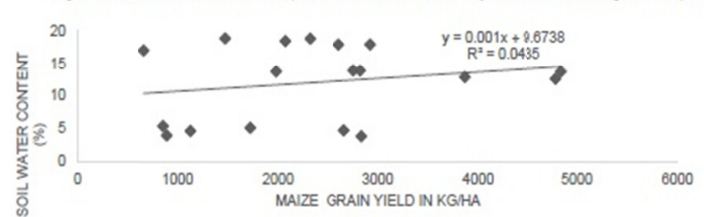

Figure $4 \mathrm{~b}$. Soil water content at the depth of $0.80-0.80 \mathrm{~m}$ and maze yeld conrelation during $2012 / 13$ planting season.

Figures 1a-4b. The correlation between soil water content and maize grain yield at different soil depths during 2011/12 and 2012/13 planting seasons 


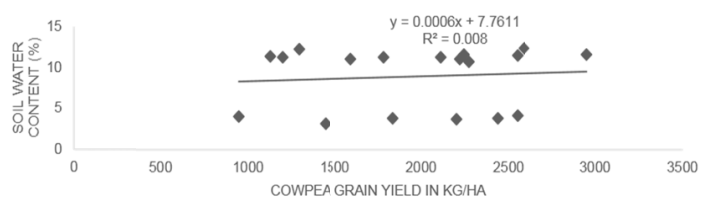

Figure 5a. Soil water content at the depth of $0-0.15 \mathrm{~m}$ and cowpea grain yield correlation during 2011/12 planting season.
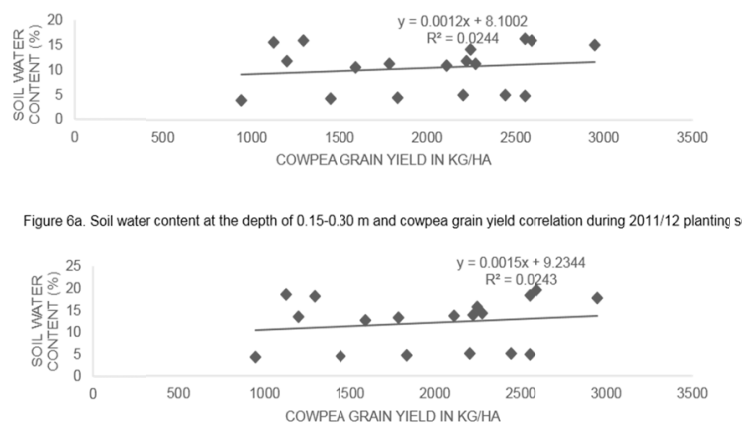

Figure 7a. Soil water content at the depth of 0.30-0.30 $\mathrm{m}$ and cowpea grain yield corelation during 2011/12 planting season.
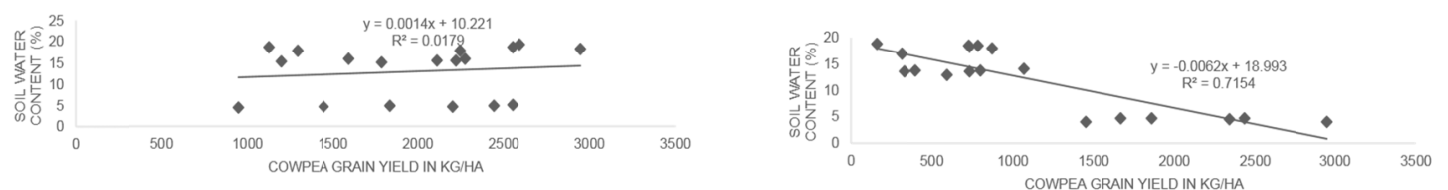

Figure 8a. Soil water content at the depth of $0.60-0.90 \mathrm{~m}$ and cowpea grain yield correlation during 2011/12 planting season.

Figure $8 \mathrm{~b}$. Soil water content at the depth of $0.60-0.90 \mathrm{~m}$ and cowpea grain yield correlation during $2012 / 13$ planting season

Figures $5 \mathrm{a}-8 \mathrm{~b}$. The correlation between soil water and cowpea grain yield at different soil depths during 2011/12 and 2012/13 planting seasons

\section{Discussion}

\subsection{The Influence of Crop Stages on Soil Water Content at Different Soil Depths}

The time of soil sampling in this study, which was before tasselling/flowering, during pod/ear formation and physiological maturity of maize-cowpea played a significant role on soil water content. This agreed with the findings by Karuma et al. (2014) who reported the significant interaction between time $\times$ cropping system on soil water content. The higher soil water content at the depths of 0-0.15, 0.15-0.30, 0.30-0.60 and 0.60-0.90 m during $\mathrm{V} 10 / \mathrm{Vn}$ growth stage of maize/cowpea may have been attributed to high crop canopy cover and occurrence of rainfall during that stage as indicated in Table 2. This implied that evaporation from soil surface was reduced and led to high availability of soil water at soil root zone. This agreed with the findings by Schwinning and Sala (2004) who reported that infiltration and evapotranspiration have been identified as key factors determining soil water content. In this study, soil water was minimal during reproductive period (VT/R4) due to high uptake of soil water during that stage. It was then assumed that, critical soil water requirements and high water uptake by crops was during VT/R4 stage. During VT/R4 growth stages, soil water content during analysis would be lower as compared to V10/Vn and R6/R8 stages. During V10/Vn and R6/R8 stages, it was always possible to find soil water in high quantity due to minimal usage by crops during those stages.

\subsection{The Influence of Location on Soil Water Content at Different Soil Depths}

The higher water content in soil collected at Rustenburg and Potchefstroom may have been attributed to the higher clay percentage in the soil compared to more sandy soil at Taung (Table 1). This agreed with the findings by Abdel-Nasser et al. (2007) that soil rich in clay content caused an increase in water holding capacity. The higher soil water at Rustenburg and Potchefstroom implied that location was also critical factor on soil water content. Dexter (2004) considered that, location with soil water retention ability could be used as indicator of soil physical quality. This implied that locality with poor soil structure will not be able to hold sufficient water to maintain good plant growth and this resulted with stunted plant growth due to reduction in absorption of plant nutrients. 


\subsection{The Influence of Cropping System on Soil Water Content at Different Soil Depths}

The higher water content in soil collected on cowpea plots planted on monocropping system may have been attributed to lower evaporation from sole cowpea plots. This corroborated the findings by Kemp et al. (1997) who reported that evapotranspiration is strongly controlled by radiation and vapour pressure deficit and crop canopy relates to the planetary boundary layer, which was the case under sole cowpea plots in this study. Ghanbari et al. (2010) found that soil water content in the soil was reduced dramatically in the sole crop of maize due to high evapotranspiration potential, on contrary soil water content in the soil was increased dramatically in the sole crop of cowpea due to low evapotranspiration potential for growth period.

This implied that, canopy cover of dense cowpea cultivar played a significant role in soil water retention due to decreased evaporation rate from soil surface. It was expected for intercropping to play a role in soil water content based on the previous studies. Adiku et al. (1998) found that intercropping has the benefits to use water from different soil layers by the companion crops and enhances overall water use efficiency. In this study, intercropping had no significant role on soil water content. It was assumed that, the cowpea cultivar (Bechuana white) which was indeterminate cultivar and covering large soil surface of the plots played a role in soil water content.

\subsection{The Interaction of Crop Growth Stages $\times$ Location $\times$ Season on Soil Water Content at Different Soil Depths}

The interaction effects of crop growth stages $\times$ location $\times$ season on soil water content had significant contribution on water conservation, since such interactions was under 0-0.15, 0.15-0.30 and 0.60-0.90 m depths. This implied that, soil water availability depends on the rate of evaporation during stages of crop growth and this was affected mainly by season and the type of location due to different soil types and climatic factors. Badel et al. (2013) found that, the effect of soil water depletion, growth stages and their interaction effect on evapotranspiration at vegetative stage were highly significant. The growth stages which reduced evaporation because of canopy cover to the soil surface, the location with good soil physical properties with sufficient organic matter and season with good climatic factors were the main factors contributing significantly to high soil water retention. In this study, the different in soil water across the locations and seasons was due to the fact that, under high humidity and cooler temperature, atmospheric evaporative demand was low, and this resulted in more soil water content as indicated in Table 2.

\subsection{The Correlation between Soil Water Content and Cowpea Grain Yield}

The positive correlation between soil water content and cowpea grain yield during the physiological maturity period may have been attributed to occurrence of rainfall during that stage of April and May of 2012/13 planting season as indicated in Table 2. The increase in soil water with increase in soil depth at Potchefstroom and Rustenburg may have been attributed to decrease in evaporation in deeper layer. This corroborated the findings by Schwinning and Sala (2004) who reported that the rates of plant water uptake increase and evaporation and vapour diffusion rates decrease in deeper soil layers. The similar soil water content in different layers of soil samples collected at Taung may have been attributed to the uniformity of soil texture (sand) from upper layers to lower layers.

\section{Conclusions}

Crop growth stage V10/Vn had higher soil water content at all different depths as compared to other growth stages. Soil collected at Rustenburg and Potchefstroom had higher water content at all different depths as compared to Taung. Cropping system had the influence on soil water content at the depth of 0.3-0.6 m only. There was no consistency in terms of season on soil water content.

Monocropping plots of cowpea had the ability to hold soil water and this depends on the type of cowpea cultivar and canopy cover. It is then recommended that, legumes should be included in cropping systems for the purpose of soil water conservation. The critical stage for high soil water content was at ear/pod formation stage (VT/R4) and this was not expected since crops use high amount of soil water during that stage. In this study, it was found that locations with high percentage of clay content were able to hold soil water during different stages of sampling. Soil water content was found to be location dependent. The production of crops such as cereals and legumes in this study are recommended to be on the area with average clay percentage. This is due to the ability of clay soil to hold water that will be accessible to crops.

\section{References}

Abdel-Nasser, G., Al-Omran, A. M., Falatah, A. M., Sheta, A. S., \& Al-Harbi, A. R. (2007). Impact of natural conditioners on water retention, infiltration and evaporation characteristics of sandy soil. Journal of Applied Sciences, 7(13), 1699-1708. https://doi.org/10.3923/jas.2007.1699.1708 
Adiku, S. G. K., Rose, C. W., Gabric, A., Braddock, R. D., Carberry, P. S., \& Mccown, R. L. (1998). An evaluation of the performance of maize and cowpea sole and intercropping systems at two savannah zones of Ghana: A simulation study. In L. M. M. Tijskens \& M. L. A. T. M. Hertog (Eds.), Proceedings of the symposium on application of modelling as an innovative technology in the agri-food chain model-IT. ACTA Horticulture 476 (pp. 251-262). International Society of Horticultural Sciences.

Akyeampong, E. (1985). Seed yield, water use, and water use efficiency of cowpea in response to drought stress at different development stages ( $\mathrm{PhD}$ Thesis, Cornel University).

Badel, M., Sarobol, E. D., \& Degewione, A. (2013). Impact of soil moisture depletion levels at different growth stages on growth, evapotranspiration and biomass yield of bread wheat grown under semi-arid condition. Agricultural Science, Engineering and Technology Research, 1(3), 26-34.

Black, C. A. (1965). Methods of Soil Analysis: Part I Physical and Mineralogical properties. American Society of Agronomy, Madison, Wisconsin, USA.

Botha, A. D. P., Snyman, H. G., Hahne, H. C. H., Prinsloo, A. L., Steenkamp, C. J., \& Duplessis, D. P. (1968). Eienskappe van die gronde van die navorsings institute vir Tabak. Tegniese Mededeling 74. Rustenburg: Department van Landbou-Tegniese Dienste.

Cakir, R. (2004). Effect of water stress at different developmental stages on vegetative and reproductive growth of corn. Field Crop Research, 89(4), 1-16. https://doi.org/10.1016/j.fcr.2004.01.005

Dexter, A. R. (2004). Soil physical quality: Part I. Theory, effect of soil texture, density and organic matter, and effect on root growth. Geoderma, 120, 201-214. https://doi.org/10.1016/j.geoderma.2003.09.004

Ghanbari, A., Dahmardeh, M., Siahsar, B. A., \& Ramroudi, M. (2010). Effect of maize (Zea mays L.)-cowpea (Vigna unguiculata L.) intercropping on light distribution, soil temperature and soil moisture in arid environment. Journal of Food, Agriculture and Environment, 8(1), 102-108.

Gomez, K. A., \& Gomez, A. A. (1984). Statistical Procedures for Agricultural Research. John Wiley and Sons. New York.

Heisey, P. W., \& Edmeades, G. O. (1999). Maize production in drought-stressed environments: Technical options and research resource allocation. World Maize Facts and Trends 1997/1998.

Hillel, D. (1998). Environmental soil physics (p. 771). San Diego: Academic Press.

Hsiao, T. C., \& Xu, L. (2005). Evapotranspiration and relative contribution by the soil and the plant (pp. 160-05). California Department of Water Resources.

Karuma, A., Mtakwa, P., Amuri, N., Gachene, C. K., \& Gicheru, P. (2014). Enhancing soil water content for increased food production in semi-arid areas of Kenya. Journal of Agricultural Science, 6(4), 125-134. https://doi.org/10.5539/jas.v6n4p125

Kemp, P. R., Reynolds, J. F., Pachepsky, Y., \& Chen, J. (1997). A comparative modelling study of soil water dynamics in a desert ecosystem. Water Resources Research, 33(1), 73-90. https://doi.org/10.1029/ 96WR03015

Leeper, G. W., \& Uren, N. C. (1993). Soil Science, an introduction (5th ed.). Melbourne University Press, Melbourne.

Macvicar, C. N., De Villiers, J. M., Loxton, R. F., Verster, E., Lambrechts, J. J. N., Merryweather, F. R., ... Harmse, H. J. (1977). Soil classification: A binomial system for South Africa. Science Bull., 390. ARC-Institute for Soil Climate and Water, Pretoria.

Muchow, R. C. (1989). Comparative productivity of maize, sorghum and pearl millet in a semi-arid tropical environment. II effects of water deficits. Field Crops Research, 20, 207-219. https://doi.org/10.1016/ 0378-4290(89)90080-4

Nandwa, S. M., \& Chege, A. G. (1996). Fertilizer use by maize in response to rainfall regimes (pp. 197-199). Fifth Eastern and Southern Africa Regional Maize Conference, June 3-7, 1996.

Ofori, E., Oteng-Darko, P., Berchie, J. N., Nimako, F. O., Yeboah, S., \& Owusu-Danguah, E. (2014). Monitoring of soil moisture regime and water use efficiency under maize-cowpea cropping system. International Journal of Current Microbiology and Applied Sciences, 3(10), 837-848.

Panday, D., \& Nkongolo, N. V. (2015). Soil water potential control of the relationship between moisture and greenhouse gas fluxes in corn-soybean field. Climate, 3, 689-696. https://doi.org/10.3390/cli3030689 
Parikh, S. J., \& James, B. R. (2012). Soil: The foundation of agriculture. Nature Education Knowledge, 3(10), 2.

Pule-Meulenberg, F., Belane, A. K., Krasova-Wadet, T., \& Dakora, F. D. (2010). Symbiotic functioning and bradyrhizobial biodiversity of cowpea (Vigna unguiculata L. Walp.) in Africa. BMC Microbiology. https://doi.org/10.1186/1471-2180-10-89

Reichert, J. M., Albuquerque, J. A., Kaiser, D. R., Reinert, D. J., Urach, F. L., \& Carlesso, R. (2009). Estimation of water retention and availability in soils of Rio Grande Do Sul. The Revista Brasileira de Ciencia do Solo, 33, 1547-1560. https://doi.org/10.1590/S0100-06832009000600004

Roder, W., Mason, S. C., Clegg, M. D., \& Kniefp, K. R. (1989). Yield-soil relationships in sorghum-soybean cropping system with different fertilizer regimes. Agronomy Journal, 8(3), 470-475. https://doi.org/10.2134/ agronj1989.00021962008100030015x

Schoonover, J. E., \& Crim, J. F. (2015). An introduction to soil concepts and the role of soils in watershed management. Journal of Contemporary Water Research \& Education, 154(1), 121-47. https://doi.org/ 10.1111/j.1936-704X.2015.03186.x

Schwinning, S., \& Sala, O. E. (2004). Hierarchy of responses to resources pulses in arid and semi-arid ecosystems. Oecologia, 141, 211-220. https://doi.org/10.1007/s00442-004-1520-8

Sebetha, E. T., Modi, A. T., \& Owoeye, L. G. (2015). Maize seed quality in response to different management practices and sites. Journal of Agricultural Science, 7(1), 215-223.

Soil Classification Working Group. (1991). Soil Classification: A Taxonomic System for South Africa. Soil and Irrigation Research Institute, Department of Agricultural Development, Pretoria.

Unger, P. W., \& Vigil, M. F. (1998). Cover crop effects on soil water relationships. Journal of Soil and Water Conservation, 53(3), 200-207.

Whalley, W. R., Ober, E. S., \& Jenkins, M. (2013). Measurement of the matric potential of soil water in the Rhizosphere. Journal of Experimental Botany, 64, 3951-3963. https://doi.org/10.1093/jxb/ert044

\section{Copyrights}

Copyright for this article is retained by the author(s), with first publication rights granted to the journal.

This is an open-access article distributed under the terms and conditions of the Creative Commons Attribution license (http://creativecommons.org/licenses/by/4.0/). 